\title{
Eksperimentasi Model Pembelajaran Kooperatif Tipe Student Teams Achievement Division (STAD) dan Tipe Jigsaw Pada Pokok Bahasan Statistika Ditinjau Dari Aktivitas Belajar Pada Siswa SMA. Oleh : M. Hamdani*
}

\begin{abstract}
Abstrak
Penelitian ini bertujuan untuk mengetahui; (1) manakah yang lebih baik prestasi belajar matematika siswa dengan model pembelajaran kooperatif tipe STAD atau kooperatif tipe Jigsaw, (2) manakah di antara kategori aktivitas belajar siswa yang memberikan prestasi belajar matematika lebih baik,aktivitas tinggi, aktivitas sedang atau aktivitas rendah (3) pada masing-masing model pembelajaran kooperatif tipe (STAD dan Jigsaw) manakah yang memberikan prestasi belajar matematika lebih baik, pada masing-masing tingkat aktivitas belajar dan masing-masing tingkat aktivitas manakah yang memberikan prestasi belajar matematika lebih baik, model pembelajaran kooperatif tipe STAD atau tipe Jigsaw.

Penelitian ini menggunakan eksperimental semu. Populasi penelitian ini adalah seluruh siswa kelas XI SMA di Kabupaten Kotawaringin Barat. Pengambilan sampel dilakukan secara Stratified Cluster Random Sampling. Teknik pengumpulan data yang digunakan adalah tes, angket dan dokumentasi. Instrumen tes untuk mengetahui prestasi belajar matematika materi statistika. Sedangkan instrumen angket untuk mengetahui aktivitas belajar siswa.

Uji prasyarat analisis adalah uji normalitas dan uji homogenitas. Uji normalitas menggunakan metode Lilliefors, diperoleh semua kelas sampel berdistribusi normal (2) uji homogenitas dengan menggunakan metode Bartlett, diperoleh semua kelas sampel mempunyai variansi yang sama.

Teknik analisis data adalah analisis varian dua jalan dengan sel tak sama. Dengan menggunakan taraf signifikansi $\alpha=0,05$ menunjukkan (1) terdapat pengaruh model pembelajaran terhadap prestasi belajar matematika pada materi statistika $\left(\mathrm{F}_{\mathrm{a}}=16,9876>3,844=\mathrm{F}_{\text {tabel }}\right)$, (2) terdapat pengaruh aktivitas belajar siswa terhadap prestasi belajar matematika pada materi statistika $\left(\mathrm{F}_{\mathrm{b}}=76,1492>3,00=\mathrm{F}_{\text {tabel }}\right)$, (3) terdapat interaksi antara model pembelajaran dan aktivitas belajar siswa terhadap prestasi belajar matematika pada materi statistika $\left(\mathrm{F}_{\mathrm{ab}}=4,94101>3,00=\mathrm{F}_{\text {tabel }}\right)$.

Hasil uji komparasi ganda dengan metode Scheffe dan dengan melihat rataan marginalnya, dapat disimpulkan bahwa: (1) Pembelajaran dengan model pembelajaran kooperatif Jigsaw memberikan prestasi belajar lebih baik dibanding dengan prestasi belajar matematika menggunakan model pembelajaran kooperatif tipe STAD.(2) Prestasi belajar siswa yang mempunyai aktivitas belajar tinggi lebih baik dibanding siswa yang mempunyai aktivitas belajar sedang dan rendah serta prestasi belajar siswa yang mempunyai aktivitas belajar sedang lebih baik dibanding siswa yang mempunyai aktivitas belajar rendah. (3) Pada kategori tingkat aktivitas tinggi, siswa yang diberi pembelajaran dengan model pembelajaran
\end{abstract}


kooperatif tipe jigsaw lebih baik prestasi belajarnya dibandingkan dengan siswa yang diberi pembelajaran dengan model pembelajaran kooperatif tipe STAD. Tetapi tidak demikian halnya, pada kategori aktivitas sedang maupun tingkat aktivitas rendah, pemberian pembelajaran dengan model pembelajaran kooperatif tipe Jigsaw maupun tipe STAD tidak menyebabkan perbedaan prestasi belajar. (4) Baik pada model pembelajaran kooperatif tipe Jigsaw maupun tipe STAD, siswa yang mempunyai aktivitas tinggi lebih baik prestasi belajarnya dibandingkan dengan siswa yang yang mempunyai aktivitas sedang dan rendah, serta siswa yang mempunyai aktivitas belajar sedang lebih baik prestasi belajarnya dibandingkan dengan siswa yang mempunyai aktivitas rendah. Sehingga untuk pembelajaran dengan menggunakan model pembelajaran kooperatif tipe Jigsaw maupun tipe STAD memberikan hasil prestasi belajar yang berbeda untuk setiap kateg aktivitas belajar yang berbeda.

Kata Kunci: Kooperatif Tipe STAD dan Jigsaw, Aktivitas, Prestasi Belajar

*Drs.M.Hamdani,M.Pd Dosen FKIP Universitas Palangkaraya

\section{Pendahuluan}

Matematika merupakan salah satu mata pelajaran yang diajarkan di sekolah dan masalah mendasar dari pembelajaran matematika adalah merupakan mata pelajaran yang sulit untuk dipahami karena matematika merupakan mata pelajaran yang abstrak. Hal ini berdampak kepada prestasi belajar siswa yang rendah, dan rendahnya prestasi belajar matematika siswa kemungkinan disebabkan pemahaman yang kurang baik dari siswa dalam menerima proses pembelajaran yang di kelola oleh guru di kelas. Hal ini ditandai dengan banyaknya siswa yang belum mencapai standar nilai matematika yang telah di tentukan, padahal standar kelulusan matematika masih rendah yaitu
5,50. Selain itu pada pokok bahasan statistika di Kelas XI SMA, siswa masih kesulitan dalam mempelajari pokok bahasan tersebut, padahal pokok bahasan ini merupakan salah satu dari materi yang termasuk standar kompetensi lulusan dalam ujian nasional.

Dalam upaya meningkatkan pembelajaran matematika, tugas seorang guru adalah menciptakan kondisi pembelajaran yang dapat membangkitkan semangat belajar siswa, sehingga siswa mempunyai keterampilan, keberanian serta mempunyai kemampuan matematika. Oleh karena itu guru sebagai pendidik perlu mempersiapkan model pembelajaran yang terprogram agar siswa memperoleh pengalaman belajar yang lebih baik. 
Dalam perkembangannya, pembelajaran matematika di sekolah telah mengalami perubahan, yaitu perubahan yang menitikberatkan dari situasi guru mengajar menjadi situasi siswa belajar. Agar pembelajaran dengan situasi siswa belajar ini dapat tercapai, maka guru dapat menggunakan strategi belajar mengajar yang lebih banyak melibatkan siswa. Selain itu menurut M.A. Simon dkk (2000:307) mengatakan bahwa: supaya pengajaran matematika lebih efektif para pengajar (guru) harus mampu mengartikualasi tujuan dan menggeneralisasi hipotesis untuk perkembangan serta pemahaman konsep dasar matematika itu sendiri.

Perubahan paradigma dalam pendidikan yaitu paradigma guru mengajar menjadi paradigma siswa belajar, menuntut komitmen guru untuk berubah. Guru harus inovatif, berpikir positif, bersikap sabar, ramah, terbuka, komunikatif dan memiliki kompetensi yang tinggi dibidangnya. Karakteristik paradigma belajar yaitu siswa aktif, guru aktif, pengetahuan dikonstruksi, menekankan proses dan produk, pembelajaran luwes dan menyenangkan serta berorientasi pada siswa. Salah satu bentuk inovasi yang dapat dilakukan adalah penerapan model pembelajaran kooperatif yang dapat membuat siswa aktif dan dapat bekerja sama dengan siswa lainnya.
Untuk

meningkatkan

pembelajaran matematika selain model pembelajaran, keberhasilan belajar siswa juga tidak terlepas dari kemampuan individu yang dimiliki siswa yang merupakan salah satu faktor internal. Dalam hal ini adalah keaktifan siswa dalam belajar. Sekolah merupakan salah satu tempat untuk mengembangkan aktivitas siswa. Dalam belajar matematika, aktivitas siswa tidak hanya mendengarkan dan mencatat materi yang dijelaskan oleh guru, namun siswa harus lebih berpartisipasi aktif, misalnya bertanya, mengerjakan soal, menjawab pertanyaan guru. Dalam melakukan aktivitas belajar siswa bervariasi, ada siswa yang aktivitas belajarnya rendah, sedang atau tinggi. Ada sebagian siswa yang tidak tertarik pada mata pelajaran matematika, karena matematika dianggap pelajaran yang sangat sulit. Bagi siswa yang kurang menyenangi pelajaran matematika, maka aktivitas belajarnya juga rendah. Ada kemungkinan hal ini akan memberikan pengaruh pada prestasi belajar siswa. Sedangkan siswa dengan aktivitas belajar yang tinggi, Ada kemungkinan prestasi belajar yang akan diperoleh menjadi tinggi, sehingga aktivitas belajar siswa sangatlah membantu dalam proses belajar matematika.

Masalah dalam penelitian ini dapat dirumuskan sebagai berikut:(1)Di antara model pembelajaran kooperatif tipe STAD 
dan tipe Jigsaw manakah yang dapat memberikan prestasi belajar matematika lebih baik? (2)Di antara katagori aktivitas belajar siswa, manakah yang dapat memberikan prestasi belajar matematika lebih baik, aktivitas tinggi, aktivitas sedang atau aktivitas rendah? (3)Pada masing-masing model pembelajaran kooperatif tipe STAD dan tipe Jigsaw manakah yang dapat memberikan prestasi belajar matematika lebih baik, siswa yang mempunyai aktivitas tinggi, aktivitas sedang atau aktivitas rendah?(4)Pada masing-masing katagori aktivitas belajar siswa ( tinggi, sedang dan rendah), manakah yang dapat memberikan prestasi belajar matematika lebih baik, model pembelajaran kooperatif tipe STAD atau kooperatif tipe Jigsaw?

Secara umum makna dari belajar adalah suatu usaha atau kegiatan dari seseorang untuk mendapatkan suatu hal yang belum dipahami atau belum diketahui sehingga akan memahami dan mengetahui tentang suatu hal yang diinginkan. Menurut Aunurahman (2010) bahwa : Belajar menunjukan suatu aktivitas pada diri seseorang yang disadari atau disengaja. Oleh sebab itu kegiatan belajar merupakan kegiatan yang disengaja atau direncanakan oleh pembelajar sendiri dalam bentuk suatu aktivitas tertentu. Aktivitas ini menunjukan pada keaktivan seseorang dalam melakukan suatu kegiatan tertentu, baik pada aspek-aspek jasmaniah maupun aspek mental yang memungkinkan terjadinya perubahan pada dirinya. Menurut Witherington dalam Aunurrahman (2010 : 35) belajar adalah suatu perubahan di dalam diri sebagai suatu pola baru dari reaksi yang berupa kecakapan, sikap, kebiasaan, kepandaian, atau suatu pengertian. Sehingga belajar adalah merupakan perubahan yang terjadi dalam diri seseorang berkaitan dengan aspek pengetahuan, keterampilan, kebiasaan, dan sikap. Pengertian matematika menurut pendapat dari beberapa ahli di antaranya adalah: menurut Herman Hudoyo (1988:3), bahwa simbolisasi dalam matematika menjamin adanya komunikasi dan mampu memberikan keterangan untuk membentuk suatu konsep baru. Konsep baru akan dapat terbentuk karena adanya pemahaman terhadap konsep sebelumnya sehingga konsepkonsep matematika tersusun secara hierarkis. Menurut Gagne, R. M dalam Soehardjo menyatakan bahwa obyek penelaahan matematika adalah fakta, keterampilan (operasi matematika) konsep dan prinsip. Obyek penelaahan ini menggunakan simbolsimbol sebagai sarana untuk melakukan penalaran. Dari beberapa pendapat di atas, dapat disimpulkan bahwa matematika berhubungan dengan aktivitas dalam praktek kehidupan sehari-hari, ide-ide atau konsep-konsep abstrak yang tersusun 
secara hierarkis dan penalarannya bersifat deduktif.

Adapun pengertian belajar matematika menurut Herman Hudoyo (1988:6), seseorang dikatakan belajar matematika bila dapat diasumsikan dalam diri orang tersebut terjadi suatu proses kegiatan yang mengakibatkan suatu perubahan tingkah laku yang berkaitan dengan matematika, dimana tingkah laku itu dapat diamati, yang diperoleh dengan adanya usaha orang tersebut. Perubahan yang disebabkan oleh proses belajar dapat ditunjukkan dalam berbagai bentuk, seperti perubahan pemahaman, perubahan pengetahuan, sikap dan tingkah laku, keterampilan serta aspek-aspek lain yang ada pada diri orang yang belajar. Belajar matematika pada dasarnya merupakan proses yang diarahkan pada suatu tujuan. Tujuan belajar matematika dapat dilihat dari kemampuan seseorang memfungsikan materi matematika yang dipelajari, baik secara konseptual maupun secara praktis. Secara konseptual dimaksudkan dapat mempelajari matematika lebih lanjut, sedangkan secara praktis dimaksudkan menerapkan matematika pada bidangbidang lain dan dalam kehidupan nyata.

Prestasi belajar matematika adalah proses belajar mengajar yang dapat menghasilkan perubahan pada diri siswa, dan perubahan tersebut berupa kemampuan diberbagai bidang yang sebelumnya tidak dimiliki siswa. Menurut Gagne dalam Winkel
(1996:482), kemampuan-kemampuan itu digolongkan atas kemampuan dalam hal informasi verbal, kemahiran intelektual, pengaturan kegiatan kognitif, kemampuan motorik dan sikap. Dan dapat dinyatakan dalam suatu prestasi belajar siswa.

Pembelajaran kooperatif adalah pendekatan pembelajaran yang berfokus pada penggunaan kelompok kecil siswa untuk bekerja sama dalam memaksimalkan kondisi belajar untuk mencapai tujuan belajar.

Menurut Harst (dalam Mau dan D Ambrosio, 2003), mengatakan bahwa: Interaksi pembelajaran dapat berlangsung saat:(1) berada dalam grup (kelompok) kecil, (2) ketika sebuah grup atau kelompok Sharing dengan grup lain, (3) ketika seorang guru mencoba untuk mengikuti keterangan dari siswa dan membuat tanggapan atas pemikiran siswa.

Pembelajaran

kooperatif merupakan salah satu bentuk pembelajaran dengan berdasar pada paham konstruktivisme. Pembelajaran kooperatif merupakan strategi belajar dimana siswa belajar pada kelompok kecil yang memiliki tingkat kemampuan yang berbeda. Dalam pembelajaran kooperatif, siswa belajar bersama dalam kelas/ kelompok-kelompok kecil yang terdiri dari 4-6 siswa, dengan tingkat kemampuan yang berbeda. Dalam menyelesaikan tugas kelompoknya, 
setiap siswa anggota kelompok harus saling bekerja sama dan saling membantu untuk memahami bahan pelajaran.

Menurut Anita Lie (2010:72), sistem pengajaran yang memberikan kesempatan kepada anak didik untuk bekerja sama dengan sesama siswa dalam tugas yang berstruktur disebut sistem pengajaran gotong royong atau cooperative learning. Dari hasil penelitian, pada beberapa bidang studi yang melibatkan suatu pelajaran yang kompleks dan memerlukan keterampilan dalam menyelesaikan, maka kerja kelompok lebih sesuai untuk mencapai tujuan dibandingkan dengan kompetisi, khususnya bagi mereka yang berkemampuan rendah.

Pendapat lain dinyatakan oleh Fengfeng $\mathrm{K}$ dan Grabowski, B (2007), bahwa dalam model pembelajaran kooperatif, keberhasilan yang dapat dicapai oleh tiap individu dalam kelompoknya sangat berarti dalam mencapai tujuan kelompok. Pembelajaran kooperatif dapat digunakan untuk meningkatkan prestasi akademik. Penelitian dalam pembelajaran matematika telah mengakui bahwa ada efek positif antara pembelajaran kooperatif dengan peningkatan kemampuan berpikir menguasai konsep.

Pembelajaran kooperatif adalah suatu sistem yang di dalamnya terdapat elemen-elemen yang saling terkait. Elemen-elemen pembelajaran kooperatif menurut Johnson, Johnson dan Holubec (1999) dalam Effandi
Zakaria dan Zonaton Iksan (2007) adalah:(1).Saling ketergantungan positif (2).Interaksi tatap muka (3). Akuntabilitas individual (4). Keterampilan menjalin hubungan antar pribadi.

Model pembelajaran kooperatif tipe STAD adalah memotivasi siswa saling memberi semangat dan membantu satu sama lain untuk menguasai materi yang diajarkan. Apabila peserta didik menginginkan timnya mendapat penghargaan mereka harus membantu teman satu tim dalam mempelajari bahan ajar/ materi tersebut.

Tahap pembelajaran model pembelajaran kooperatif tipe STAD menurut M. Nur ( dalam Trianto, 2005:20) antara lain meliputi:(1)Presentasi kelas atau tahap Penyajian Materi (2) Kerja Kelompok (3) Pelaksanaan kuis individu (4) Nilai perkembangan individu (5) Penghargaan kelompok.

Model pembelajaran kooperatif tipe Jigsaw adalah pembelajaran kooperatif yang terdiri dari beberapa anggota dalam satu kelompok yang bertanggung jawab atas penguasaan bagian materi belajar dan mampu mengajarkan bagian tersebut kepada anggota lain dalam kelompoknya (Arends, 1997:73).

Jigsaw dikembangkan dan diuji oleh Eliot Aronso, kemudian digunakan oleh Slavin dan temannya (Arens,RI,1997:72).

Dalam 
pembelajaran kooperatif jigsaw ini, siswa belajar / bekerja dalam kelompok yang heterogen dan beranggotakan 4-6 orang, yang disebut kelompok asal. Setiap anggota kelompok bertangung jawab atas penguasaan bagian dari materi belajar yang ditugaskan padanya, kemudian mengajarkan bagian tersebut kepada anggota kelompok lain. Masingmasing anggota kelompok yang mendapat tugas penguasaan bagian tersebut kepada anggota kelompok lain. Masing-masing anggota kelompok yang mendapat tugas penguasaan bagian materi itu disebut ahli. Keahlian tersebut dapat diperoleh dari menawarkan bagian materi kepada anggota kelompok menurut dari kelompok yang berbeda dengan topik yang sama (ahli) bertemu untuk berdiskusi antar ahli. Mereka dapat saling membantu satu sama lain tentang topik yang ditugaskan, serta mendiskusikannya. Setelah itu siswa pada kelompok ahli kembali ke kelompok yang lainnya dari apa yang dibahas/dan dipelajari dalam kelompok ahli. Masing-masing anggota kelompok asal bertemu dalam diskusi kelompok ahli untuk membahas materi yang ditugaskan. Setelah selesai berdiskusi dalam kelompok ahli, kembali pada kelompok asal untuk menjelaskan pada teman sekelompoknya. Jigsaw di desain tidak hanya untuk meningkatkan rasa tanggung jawab secara mandiri, tetapi juga dituntut untuk saling ketergantungan dalam arti positif terhadap teman sekelompoknya.

Dalam kegiatan belajar mengajar, aktivitas yang dimaksud adalah aktivitas yang bersifat fisik maupun mental. Keduanya harus selalu terkait (Nasution, 1995:89).

Pendapat lain yang dikemukakan oleh Rousseau dalam Sardiman A.M (1994:95) memberikan penjelasan bahwa dalam kegiatan belajar segala pengetahuan harus diperoleh dengan pengamatan sendiri, pengalaman sendiri, penyelidikan sendiri, dengan bekerja sendiri, dengan fasilitas yang diciptakan sendiri, baik secara rohani maupun teknis. Hal ini menunjukan bahwa setiap orang yang bekerja harus aktif sendiri, tanpa adanya aktivitas maka proses belajar tidak mungkin terjadi.

Dari beberapa pendapat di atas diperoleh kesimpulan bahwa aktivitas belajar siswa adalah kegiatan belajar yang dilakukan siswa dengan cara mengamati sendiri, menyelidiki sendiri dan bekerja secara aktif dengan fasilitas yang diciptakan sendiri untuk berkembang sendiri dengan bimbingan dan pengamatan dari guru.

Aktivitas belajar siswa dalam penelitian ini adalah : (1).Waktu untuk belajar matematika, yang meliputi frekuensi partisipasi belajar matematika dan waktu yang digunakan.(2).Sikap dalam mengikuti pelajaran matematika, yang meliputi partisipasi dalam mengikuti pelajaran 
matematika, mengikuti jam kosong, sikap dalam mengerjakan setiap tugas di sekolah. (3).Belajar matematika sendiri, yang meliputi mengatasi kesulitan dalam belajar matematika di rumah, belajar di luar sekolah atau les. (4).Belajar matematika secara kelompok, yang meliputi partisipasi dalam belajar kelompok, mengatasi kesulitan dalam belajar secara kelompok. (5).Mengerjakan tugas, latihan atau pekerjaan rumah, yang meliputi mengerjakan pekerjaan rumah yang diberikan, sikap dalam menghadapi pekerjaan rumah yang sulit.

\section{Metode Penelitian}

Penelitian ini tergolong penelitian eksperimen semu (Quasi experimental) bertujuan untuk mengetahui; (1) manakah yang lebih baik prestasi belajar matematika siswa dengan model pembelajaran kooperatif tipe STAD atau kooperatif tipe Jigsaw, (2) manakah di antara kategori aktivitas belajar siswa yang memberikan prestasi belajar matematika yang lebih baik,aktivitas tinggi, aktivitas sedang atau aktivitas rendah (3) pada masing-masing model pembelajaran kooperatif tipe (STAD dan Jigsaw) manakah yang memberikan prestasi belajar matematika lebih baik, pada masing-masing tingkat aktivitas belajar dan masing-masing tingkat aktivitas manakah yang memberikan prestasi belajar matematika lebih baik, model pembelajaran kooperatif tipe STAD atau tipe Jigsaw dan dilaksanakan di Sekolah Menengah Atas (SMA) Se Kabupaten Kotawaringin Barat dengan sampel SMA-1 Pangkalan Bun, SMA-1 Kumai dan SMA PGRI Pangkalan Bun, dengan teknik pengambilan sampel adalah stratified cluster random sampling (sampel random kelas stratifikasi) karena terdapat tingkatan atau strata dalam populasi. Menurut Budiyono (2003 : 37) sampling random stratifikasi adalah sampling random yang dikenakan kepada populasi dibagi menurut stratastrata, kemudian dari strata-strata tersebut ditarik anggota kelas-kelas sampel secara random dari subpopulasinya (yaitu strata-strata tadi).

Rancangan yang digunakan dalam penelitian ini adalah rancangan faktorial $2 \times 3$.

\begin{tabular}{|l|l|l|l|}
\hline $\mathrm{B}$ & $\mathrm{b}_{1}$ & $\mathrm{~b}_{2}$ & $\mathrm{~b}_{3}$ \\
$\mathrm{~A}$ & & & \\
\hline $\mathrm{a}$ & $(\mathrm{a}$ & $(\mathrm{a}$ & $(\mathrm{a}$ \\
1 & $\mathrm{~b})_{1}$ & $\mathrm{~b})_{1}$ & $\mathrm{~b})_{1}$ \\
$\mathrm{a}$ & 1 & 2 & 3 \\
2 & $(\mathrm{a}$ & $(\mathrm{a}$ & $(\mathrm{a}$ \\
& $\mathrm{b})_{2}$ & $\mathrm{~b})_{2}$ & $\mathrm{~b})_{2}$ \\
& 1 & 2 & 3 \\
\hline
\end{tabular}

Keterangan :

A : Model pembelajaran 
$a_{1}$ : Model pembelajaran kooperatif tipe Jigsaw

$a_{2}$ : Model pembelajaran kooperatif tipe STAD

B : Aktivitas belajar

$\mathrm{b}_{1}$ : Aktivitas tinggi

$\mathrm{b}_{2}$ : Aktivitas sedang

$\mathrm{b}_{3}$ : Aktivitas rendah

Metode pengumpulan

data dalam penelitian ini adalah

menggunakan:

(1).Metode

dokumentasi yaitu mendapatkan data nilai raport mata pelajaran matematika untuk uji keseimbangan kedua kelompok eksperimen.(2).Metode Angket yaitu untuk mendapatkan data aktivitas belajar siswa dan (3).Metode Tes yaitu untuk mendapatkan data prestasi belajar siswa dan sebelumnya telah dilakukan Uji validitas dan reliabilitas untuk mengetahui kualitas instrumen tes, dengan melakukan validitas isi, daya pembeda, tingkat kesukaran dan uji reliabilitas.

Dalam penelitian ini untuk menganalisa data digunakan analisis variansi dua jalan $(2 \times 3)$ dengan frekuensi sel tidak sama dan sebelumnya dilakukan uji prasyarat analisis yaitu uji normalitas dan uji homogenitas. Adapun tujuan Analisis variansi dua jalan yang merupakan perluasan dari analisis variansi dua jalan, bertujuan untuk membandingkan rata - rata beberapa populasi baik rata - rata baris maupun kolom dalam sel. Anava dua jalan bertujuan untuk menguji signifikansi perbedaan efek baris, kolom dan kombinasi efek baris dan kolom terhadap variabel terikat.

Rangkuman Uji

\begin{tabular}{|l|l|l|l|l|l|l|}
\hline $\begin{array}{l}\text { Sumber var } \\
\text { efek utama }\end{array}$ & JK & Dk & RK & F obs & F $\alpha$ & P \\
\hline A baris & JKA & P - 1 & RKA & $F_{a}$ & & $<\alpha$ atau $>\alpha$ \\
\hline B kolom & JKB & q -1 & RKB & $F_{b}$ & & $<\alpha$ atau $>\alpha$ \\
\hline Interaksi AB & JKAB & (p-1)(q-1) & RKAB & $F_{\text {ab }}$ & & $<\alpha$ atau $>\alpha$ \\
\hline Galat(G) & JKG & N-pq & RKG & - & & - \\
\hline Total & JKT & N-1 & - & - & & - \\
\hline
\end{tabular}

Keputusan uji

$\mathrm{H}_{0}$ ditolak jika $\mathrm{F}_{\text {hitung }}$ terletak di daerah kritik (Budiyono, 2009:215)

Uji Lanjut Anava adalah tindak lanjut dari analisis varian, jika hasil analisis variansi menunjukkan hipotesis nol ditolak. Tujuannya untuk melakukan pelacakan terhadap perbedaan rerata tetapi setiap pasangan kolom, baris dan setiap pasangan sel. Metode komparasi ganda yang dipakai adalah metode Scheffe.

\section{Hasil Penelitian dan Pembahasan}

Berdasarkan hasil uji validitas isi instrumen tes, uji tingkat Kesukaran instrumen tes, uji daya beda instrumen tes dan uji reliabilitas instrumen tes dapat dirangkum bahwa dari 35 soal tes yang diuji coba diperoleh 31 soal yang termasuk katagori valid.

Data nilai aktivitas belajar siswa dengan melalui angket aktivitas belajar siswa yaitu : Rata- 
rata nilai untuk kelas Jigsaw adalah 109,2820 dan rata-rata kelas STAD adalah 107,8608 sedangkan rata keseluruhan siswa kelas Jigsaw dan kelas STAD adalah $\quad 108,5669$.

Hasil pengolahan data Aktivitas Belajar siswa, dapat dilihat standart deviasi untuk kelas Jigsaw adalah 8,6413. Sedangkan standart deviasi untuk kelas STAD adalah 8,9946. Dari standar deviasi maka dapat dilihat kriteria Aktivitas belajar siswa yang dibagi menjadi tinggi, sedang

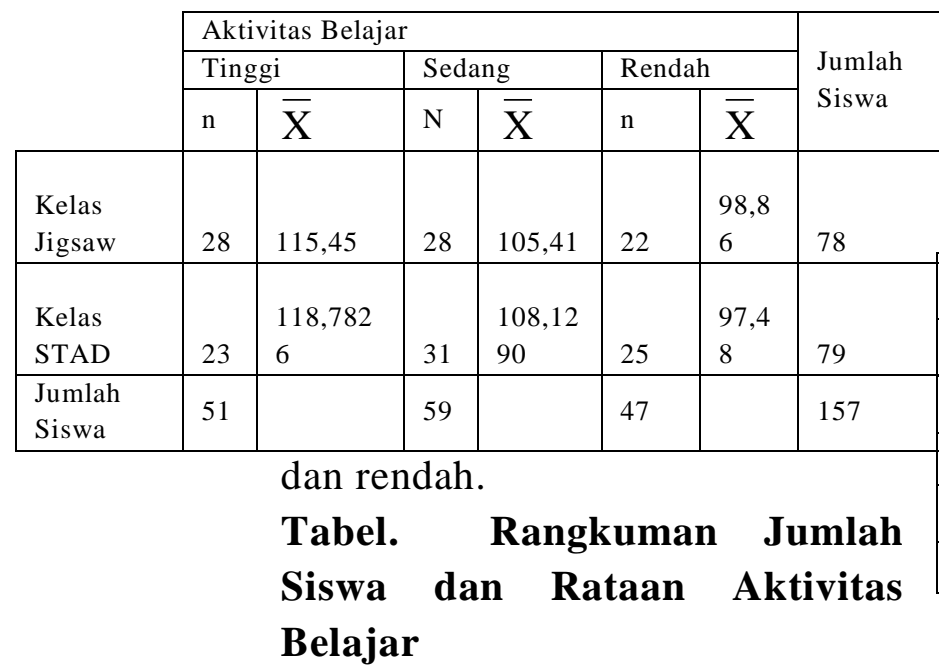

Berdasarkan hasil tes prestasi belajar setelah dilakukan pembelajaran dengan model pembelajaran kooperatif tipe Jigsaw dan kooperatif tipe STAD maka hasil dari prestasi belajar siswa dapat dilihat pada tabel berikut :

Tabel. Rangkuman Rataan Prestasi Belajar Siswa
Tabel. Rangkuman Analisis Variansi Dua Jalan Sel Tak Sama

Dari tabel rangkuman analisis variansi dua jalan sel tak sama terlihat dan disimpulkan bahwa : (1)Pada hasil $F_{a}$ faktor (A) lebih dari $\mathrm{F}_{\text {Tabel }}$ maka $\mathrm{H}_{0 \mathrm{~A}}$ ditolak sehingga dikatakan tidak semua model pembelajaran memberikan rataan yang sama terhadap prestasi belajar. 
Dengan melihat rataan prestasi belajar siswa dikatakan bahwa pembelajaran dengan model pembelajaran kooperatif tipe Jigsaw lebih baik dari pada dengan model pembelajaran kooperatif tipe STAD.

Pada hasil $F_{b}$ faktor (B) lebih dari $\mathrm{F}_{\text {tabel }}$ maka $\mathrm{H}_{0 \mathrm{~B}}$ ditolak sehingga dikatakan tidak semua kriteria Aktivitas Belajar memberikan rataan yang sama terhadap prestasi belajar.

Pada hasil $\mathrm{F}_{\mathrm{ab}}$ faktor $(\mathrm{AB})$ lebih dari $\mathrm{F}_{\text {tabel }}$ maka $\mathrm{H}_{0 \mathrm{AB}}$ ditolak maka dikatakan bahwa faktor (A) dan faktor (B) menunjukkan terdapat interaksi antara metode pembelajaran dan Aktivitas Belajar siswa terhadap prestasi belajar siswa.

Hasil Uji lanjut Hipotesis Komparasi Ganda Antar Kolom

Uji lanjut analisis variansi dua jalan dengan sel tak sama dengan menggunakan metode Scheffe.

\section{Tabel Rangkuman Data}

Komparasi Ganda Antar Kolom

\begin{tabular}{|c|c|c|c|}
\hline $\mathrm{H}_{0}$ & $\mathrm{~F}_{\text {hitung }}$ & $\mathrm{F}_{\text {tabel }}$ & Keputusan \\
\hline $\begin{array}{l}\mu_{\cdot 1}= \\
\mu_{\cdot 2}\end{array}$ & 49,75443518821 & $\begin{array}{l}(3-1) . \\
3,00= \\
6\end{array}$ & $\begin{array}{l}\mathrm{H}_{0} \\
\text { ditolak }\end{array}$ \\
\hline $\begin{array}{l}\mu_{.2}= \\
\mu_{\cdot 3}=\end{array}$ & 25,71501394755 & $\begin{array}{l}(3-1) \\
3,00= \\
6\end{array}$ & $\begin{array}{l}\mathrm{H}_{0} \\
\text { ditolak }\end{array}$ \\
\hline $\begin{array}{l}\mu_{.1}= \\
\mu_{.3}\end{array}$ & 133,94097301858 & $\begin{array}{l}(3-1) . \\
3,00= \\
6\end{array}$ & $\mathrm{H}_{0}$ ditolak \\
\hline
\end{tabular}

Dari Tabel rangkuman data komparasi ganda antar kolom disimpulkan :
1. Prestasi belajar pada siswa yang mempunyai aktivitas Belajar tinggi lebih baik dari pada siswa yang berkemampuan sedang.

2. Prestasi belajar pada siswa yang mempunyai aktivitas Belajar sedang lebih baik dari pada siswa yang berkemampuan rendah.

3. Prestasi belajar pada siswa yang mempunyai aktivitas Belajar tinggi lebih baik dari pada siswa yang berkemampuan rendah.

Uji lanjut analisis variansi dua jalan dengan sel tak sama dengan menggunakan metode Scheffe.

Tabel - Rangkuman Komparasi Ganda Antar Sel Pada Kolom yang sama

\begin{tabular}{|l|l|l|l|}
\hline $\mathrm{H}_{0}$ & $\mathrm{~F}_{\text {hitung }}$ & $\mathrm{F}_{\text {tabel }}$ & Keputusan \\
\hline$\mu_{11}=\mu_{21}$ & 23,95418049607 & $\begin{array}{l}(6-1) .2,21 \\
11,05\end{array}$ & $\mathrm{H}_{0}$ ditolak \\
\hline$\mu_{12}=\mu_{22}$ & 1,42947688442 & $\begin{array}{l}(6-1) .2,21 \\
11,05\end{array}$ & $\mathrm{H}_{0}$ diterima \\
\hline$\mu_{13}=\mu_{23}$ & 1,04513806913 & $\begin{array}{l}(6-1) .2,21 \\
11,05\end{array}$ & $\mathrm{H}_{0}$ diterima \\
\hline
\end{tabular}

Dari Tabel rangkuman

data komparasi ganda antar sel pada kolom yang sama dapat disimpulkan :

1. Pada Aktivitas Belajar tinggi prestasi belajar pada siswa dengan menggunakan model pembelajaran kooperatif tipe Jigsaw lebih baik dari pada prestasi belajar siswa dengan metode pembelajaran kooperatif tipe STAD. 
2. Pada Aktivitas Belajar sedang prestasi belajar pada siswa dengan menggunakan metode pembelajaran kooperatif tipe Jigsaw sama dengan prestasi belajar siswa dengan metode pembelajaran kooperatif tipe STAD.

3. Pada Aktivitas Belajar rendah prestasi belajar pada siswa dengan menggunakan metode pembelajaran kooperatif tipe Jigsaw sama dengan prestasi belajar siswa dengan metode pembelajaran kooperatif tipe STAD.

Uji lanjut analisis variansi dua jalan dengan sel tak sama dengan menggunakan metode Scheffe.

Tabel . Rangkuman Komparasi Ganda Antar Sel pada Baris yang Sama

\begin{tabular}{|c|c|c|c|}
\hline$\overline{\mathrm{H}_{0}}$ & $F_{\text {hitung }}$ & $\mathrm{F}_{\text {tabel }}$ & Keputusan \\
\hline $\begin{array}{l}\mu_{11}= \\
\mu_{12}\end{array}$ & 50,56284199703 & $\begin{array}{l}(6- \\
1) . \\
2,21 \\
= \\
11,05\end{array}$ & $\mathrm{H}_{0}$ ditolak \\
\hline $\begin{array}{l}\mu_{12}= \\
\mu_{13}\end{array}$ & 13,82531715296 & $\begin{array}{l}(6- \\
1) . \\
2,21 \\
= \\
11,05\end{array}$ & $\mathrm{H}_{0}$ ditolak \\
\hline $\begin{array}{l}\mu_{11}= \\
\mu_{13}\end{array}$ & 104,70093311972 & $\begin{array}{l}(6- \\
1) . \\
2,21 \\
= \\
11,05\end{array}$ & $\mathrm{H}_{0}$ ditolak \\
\hline $\begin{array}{l}\mu_{21}= \\
\mu_{22}\end{array}$ & 11,12171512344 & $\begin{array}{l}(6- \\
1) . \\
2,21 \\
= \\
11,05\end{array}$ & $\mathrm{H}_{0}$ ditolak \\
\hline $\begin{array}{l}\mu_{22}= \\
\mu_{23}\end{array}$ & 11,99284192874 & $\begin{array}{l}(6- \\
1) . \\
2,21 \\
= \\
11,05\end{array}$ & $\mathrm{H}_{0}$ ditolak \\
\hline
\end{tabular}

\begin{tabular}{|l|l|l|l|}
\hline$\mu_{21}=$ & & $(6-$ & $\mathrm{H}_{0}$ ditolak \\
$\mu_{23}$ & & $1)$ & \\
& 43,44792344316 & 2,21 & \\
& & $\begin{array}{l} \\
=\end{array}$ & \\
& & 11,05 & \\
\hline
\end{tabular}

Dari Tabel rangkuman data komparasi ganda antar sel pada kolom yang sama dapat disimpulkan bahwa :

1. Pada pembelajaran kooperatif tipe Jigsaw, prestasi belajar siswa aktivitas belajar tinggi lebih baik dari pada siswa aktivitas belajar sedang.

2. Pada pembelajaran kooperatif tipe Jigsaw, prestasi belajar siswa kemampuan sedang lebih baik dari pada siswa berkemampuan rendah.

3. Pada pembelajaran kooperatif tipe Jigsaw, prestasi belajar siswa kemampuan tinggi lebih baik dari pada siswa berkemampuan rendah.

4. Pada pembelajaran kooperatif tipe STAD, prestasi belajar siswa kemampuan tinggi lebih baik dari pada siswa berkemampuan sedang.

5. Pada pembelajaran kooperatif tipe STAD, prestasi belajar siswa kemampuan sedang lebih baik dari pada siswa berkemampuan rendah.

6. Pada pembelajaran kooperatif tipe STAD, prestasi belajar siswa kemampuan tinggi lebih baik dari pada siswa berkemampuan rendah.

Pembahasan Hasil Penelitian 
Hasil analisis variansi dua jalan sel tak sama dengan $\alpha$ $=0,05$ diperoleh $\mathrm{F}_{\mathrm{a}}=16,9876$ lebih dari $\mathrm{F}_{\text {tabel }}=3,84$ sehingga $\mathrm{H}_{0 \mathrm{~A}}$ ditolak. Ini berarti model pembelajaran kooperatif tipe Jigsaw dan STAD memberikan hasil prestasi belajar siswa yang berbeda pada pokok bahasan Statistika SMA kelas XI. Dengan melihat rataan prestasi belajar siswa dikatakan bahwa pembelajaran kooperatif tipe Jigsaw lebih baik dari pada dengan pembelajaran kooperatif tipe STAD. Hipotesis pertama teruji.

Hasil analisis variansi dua jalan sel tak sama dengan $\alpha$ $=0,05$ diperoleh $F_{b}=76,1492$ lebih dari $\mathrm{F}_{\text {tabel }}=3,000$ sehingga $\mathrm{H}_{0 \mathrm{~B}}$ ditolak. Ini berarti Aktivitas Belajar siswa yang berkemampuan tinggi, sedang, dan rendah memberikan hasil prestasi belajar siswa yang berbeda pada pokok bahasan Statistika SMA.

Dari uji lanjut pasca anava diperoleh perhitungan komparasi ganda antar kolom dengan $\alpha=0,05$ diperoleh $\mathrm{F}_{1-2}=$ 49,7544 lebih dari $\mathrm{F}_{\text {tabel }}=6,000$ sehingga $\mathrm{H}_{0}$ ditolak. Ini berarti, siswa yang mempunyai aktivitas belajar tinggi mempunyai prestasi belajar matematika lebih baik dari pada siswa yang mempunyai aktivitas belajar sedang. Selanjutnya, pada kolom kedua dan ketiga diperoleh $\mathrm{F}_{2-3}=25,7150$ lebih dari $\mathrm{F}_{\text {tabel }}=6,000$ sehingga $\mathrm{H}_{0}$ ditolak. Dapat dikatakan bahwa siswa yang mempunyai aktivitas belajar sedang mempunyai prestasi belajar matematika lebih baik dari pada siswa yang mempunyai aktivitas belajar rendah. Pada kolom kesatu dan ketiga diperoleh $\mathrm{F}_{1-3}=133,9409$ lebih dari $\mathrm{F}_{\text {tabel }}=$ 6,000 sehingga $\mathrm{H}_{0}$ ditolak. Berarti siswa yang mempunyai mempunyai aktivitas belajar tinggi mempunyai prestasi belajar matematika lebih baik dari pada siswa yang mempunyai aktivitas belajar rendah. Hipotesis kedua dikatakan teruji untuk hasil prestasi belajar siswa yang mempunyai aktivitas belajar tinggi lebih baik dari pada siswa yang mempunyai aktivitas belajar sedang. Begitu juga untuk prestasi belajar pada siswa yang mempunyai aktivitas belajar sedang lebih baik daripada prestasi belajar pada siswa yang mempunyai aktivitas belajar rendah dan hasil prestasi belajar siswa yang mempunyai aktivitas belajar tinggi lebih baik dari pada siswa yang mempunyai aktivitas belajar rendah.

Hasil analisis variansi dua jalan sel tak sama dengan $\alpha=$ 0,05 diperoleh $\mathrm{F}_{\mathrm{ab}}=4,9410$ lebih dari $\mathrm{F}_{\text {tabel }}=3,000$ sehingga $\mathrm{H}_{0 \mathrm{AB}}$ ditolak. Ini berarti terdapat interaksi antara model pembelajaran dan Aktivitas Belajar siswa terhadap prestasi belajar siswa pada pokok bahasan Statistika SMA kelas XI. 
Hasil perhitungan
komparasi ganda antar sel pada kolom yang sama dengan $\alpha=0,05$. Pada kolom pertama diperoleh $\mathrm{F}_{11}$ $21=23,95418$ kurang dari $\mathrm{F}_{\text {tabel }}=$ 11,0500 dan sehingga $\mathrm{H}_{0}$ diterima, maka dapat dikatakan bahwa pada siswa yang mempunyai aktivitas belajar tinggi pembelajaran dengan model pembelajaran kooperatif tipe Jigsaw memberikan prestasi belajar matematika yang lebih baik dari pada prestasi belajar matematika dengan model pembelajaran kooperatif tipe STAD. Selanjutnya pada kolom kedua diperoleh $\mathrm{F}_{12-22}=$ 1,42947 kurang dari $F_{\text {tabel }}=$ 11,0500 sehingga $\mathrm{H}_{0}$ diterima, maka dapat dikatakan bahwa pada siswa yang mempunyai aktivitas belajar sedang pembelajaran dengan model pembelajaran kooperatif tipe Jigsaw memberikan prestasi belajar matematika sama dengan prestasi belajar matematika dengan model pembelajaran kooperatif tipe STAD. Pada kolom ketiga diperoleh $\mathrm{F}_{13-23}=1,04513$ kurang dari $\mathrm{F}_{\text {tabel }}=11,0500$ sehingga $\mathrm{H}_{0}$ diterima, hal ini dikatakan bahwa pada siswa yang mempunyai aktivitas belajar rendah pembelajaran dengan model pembelajaran kooperatif tipe Jigsaw memberikan prestasi belajar matematika sama dengan prestasi belajar matematika dengan model pembelajaran kooperatif tipe STAD. Dapat disimpulkan bahwa untuk setiap kategori Aktivitas belajar siswa mempunyai prestasi belajar yang sama jika diberikan pembelajaran dengan menggunakan model pembelajaan kooperatif tipe Jigsaw maupun kooperatif tipe STAD. Dapat dikatakan bahwa hipotesis penelitian ketiga teruji sebab dengan penggunaan model pembelajaran kooperatif tipe Jigsaw maupun kooperatif tipe STAD pada siswa yang mempunyai Aktivitas Belajar yang berbeda mendapatkan prestasi belajar yang berbeda pula. Hal ini sesuai dari yang diharapkan dari hipotesis ketiga adalah pada siswa yang mempunyai Aktivitas Belajar sedang maupun rendah dengan pembelajaran menggunakan model pembelajaran kooperatif tipe Jigsaw memberikan prestasi belajar matematika pokok bahasan Statistika lebih baik dari pada pembelajaran dengan menggunakan model pembelajaran kooperatif tipe STAD.

Pada hasil yang lain untuk perhitungan komparasi ganda antar sel pada baris pertama kolom kesatu dan kedua diperoleh $\mathrm{F}_{11-12}=$ 50,5628 lebih dari $\mathrm{F}_{\text {Tabel }}=11,0500$ sehingga $\mathrm{H}_{0}$ ditolak, Bahwa pembelajaran dengan model pembelajaran kooperatif tipe Jigsaw, prestasi belajar siswa pada aktivitas belajar tinggi lebih baik dari pada siswa yang mempunyai aktivitas belajar sedang. Berikut pada sel baris pertama kolom kedua dan ketiga diperoleh $\mathrm{F}_{12-13}=$ 
13,8253 lebih dari $\mathrm{F}_{\text {Tabel }}=11,0500$ sehingga $\mathrm{H}_{0}$ ditolak, dikatakan bahwa pembelajaran dengan model pembelajaran kooperatif tipe Jigsaw, prestasi belajar siswa pada aktivitas belajar sedang lebih baik dari pada siswa yang mempunyai aktivitas belajar rendah. Pada sel baris pertama kolom kesatu dan ketiga diperoleh $\mathrm{F}_{11-13}=104,7009$ lebih dari $\mathrm{F}_{\text {Tabel }}=11,0500$ sehingga $\mathrm{H}_{0}$ ditolak, dikatakan bahwa pembelajaran dengan model pembelajaran kooperatif tipe Jigsaw, prestasi belajar siswa pada aktivitas belajar tinggi lebih baik dari pada siswa yang mempunyai aktivitas belajar rendah.

$$
\text { Hasil perhitungan }
$$

komparasi ganda antar sel pada baris kedua kolom kesatu dan kedua diperoleh $\mathrm{F}_{21-22}=11,1217$ lebih dari $\mathrm{F}_{\text {Tabel }}=11,0500$ sehingga $\mathrm{H}_{0}$ ditolak, dikatakan bahwa pembelajaran dengan model pembelajaran kooperatif STAD, prestasi belajar siswa pada aktivitas belajar tinggi lebih baik dari pada siswa yang mempunyai aktivitas belajar sedang. Kemudian sel pada baris kedua kolom kedua dan ketiga diperoleh $\mathrm{F}_{22-23}=11,9928$ lebih dari $\mathrm{F}_{\text {Tabel }}=11,0500$ sehingga $\mathrm{H}_{0}$ ditolak. Hal ini mempunyai arti bahwa pembelajaran dengan model pembelajaran kooperatif tipe STAD, prestasi belajar siswa pada aktivitas belajar sedang lebih baik dari pada siswa yang mempunyai aktivitas belajar rendah. Pada sel baris kedua kolom kesatu dan ketiga diperoleh $\mathrm{F}_{21-23}=43,4479$ lebih dari $\mathrm{F}_{\text {Tabel }}=11,0500$ sehingga $\mathrm{H}_{0}$ ditolak maka dikatakan bahwa pembelajaran dengan model pembelajaran kooperatif tipe STAD, prestasi belajar siswa pada aktivitas belajar tinggi lebih baik dari pada siswa yang mempunyai aktivitas belajar rendah. Pembelajaran dengan menggunakan model pembelajaran kooperatif tipe Jigsaw maupun kooperatif tipe STAD memberikan hasil prestasi belajar yang berbeda untuk setiap kategori aktivitas belajar yang berbeda.

\section{Kesimpulan}

Dari data hasil penelitian ini diperoleh kesimpulan berikut ini:

(1).Pada pembelajaran dengan model pembelajaran kooperatif Jigsaw mempunyai prestasi belajar yang lebih baik dibanding dengan prestasi belajar matematika yang menggunakan model pembelajaran kooperatif tipe STAD.

(2).Prestasi belajar siswa yang mempunyai aktivitas belajar tinggi lebih baik dari pada siswa yang mempunyai aktivitas belajar sedang, prestasi belajar siswa yang mempunyai aktivitas belajar sedang lebih baik dari pada siswa yang mempunyai aktivitas belajar rendah, begitu 
juga prestasi belajar siswa yang mempunyai aktivitas belajar tinggi lebih baik dari pada siswa yang mempunyai aktivitas belajar rendah.

(3).Pada kategori tingkat aktivitas tinggi, siswa yang diberi pembelajaran dengan model pembelajaran kooperatif tipe jigsaw lebih baik prestasi belajarnya dibandingkan dengan siswa yang diberi pembelajaran dengan metode pembelajaran kooperatif tipe STAD. Tetapi tidak demikian halnya, pada kategori aktivitas sedang maupun tingkat aktivitas rendah, pemberian pembelajaran dengan metode pembelajaran kooperatif tipe Jigsaw maupun tipe STAD tidak menyebabkan perbedaan prestasi belajar.

(4).Baik pada model pembelajaran kooperatif tipe Jigsaw maupun tipe STAD, siswa yang mempunyai aktivitas tinggi lebih baik prestasi belajarnya dibandingkan dengan siswa yang yang mempunyai aktivitas sedang dan rendah, serta siswa yang mempunyai aktivitas sedang lebih baik prestasi belajarnya dibandingkan dengan siswa yang mempunyai aktivitas rendah. Sehingga untuk pembelajaran dengan menggunakan model pembelajaran kooperatif tipe Jigsaw maupun kooperatif tipe
STAD memberikan hasil prestasi belajar yang berbeda untuk setiap kategori aktivitas belajar yang berbeda. 


\section{DAFTAR PUSTAKA}

Anita Lie, 2010. Cooperative Learning. Jakarta: PT. Gramedia.

Arends, Richard I, 1997. Classroom Instructional and Management. Central Connecticut State University: The McGraw-Hill Companies Inc.

Aunurrahman, 2010. Belajar dan Pembelajaran. Bandung: Penerbit Alfabeta.

Budiyono, 2003. Metodologi Penelitian Pengajaran Matematika.Surakarta: UNS Press.

Budiyono, 2009. Statistika untuk penelitian. Surakarta: UNS Press

Effandi Zakaria dan Zanaton Iksan, 2007. "Promoting Cooperative Learning in Science and Mathematics Education: A Malaysian Persepective". Eurasia Journal of Mathematics, Science \& Technology Education. Volume 3, Nomor 1, page 35-39.

Fengfeng K dan Graboski,B. 2007. "Gameplaying for maths Learning".British Journal of Educational Technology. Volume 38, Nomor 2, page 249-250.

Herman Hudoyo, 1988. Mengajar Belajar Matematika. Depdikbud, Jakarta P2LPTK.

Mau, Sue and D Ambrosio, Beatriz, 2003. Extending Ourselves: Making Sense of Students Sense Making. Brisbane. The University of Melbourne. Mathematics Teacher Education \& Development. Vol 5. page 44-52

Simon, MA dkk, 2000. Characterizing Underlying the Practice of Mathematics Teacher in Transilion. San Diego University. Journal for Mathematics Education San Diego. Vol 15.No.5 Page $305-329$.

Sardiman A.M, 2009. Interaksi dan Motivasi Belajar Mengajar. Jakarta: Raja Grafindo.

Slavin, Robert E, 1994. Educational Psychology: Theory and Practice. Fourth Edition, Massachusets: Allyn and Bacon Publishers. 
Slavin. Robert E. 1995. Cooperative Learning Theory and Practice, Second Edition. Boston: Allyn and Bacon Publishers.

Soehardjo,1992. Strategi Belajar Mengajar Matematika.Surakarta: UNS Press.

Trianto, 2007. Model-model Pembelajaran Inovatif, Berorientasi Konstruktivistik Konsep, Landasan Teoritis-Praktis dan Implementasinya. Jakarta: Prestasi Pustaka Publisher.

Winkel W.S, 1996. Psikologi Pengajaran, Jakarta: Grasindo. 